\title{
Balbina Hoppe: Fantom, światło, fragment. Schulz w teatrze cieni
}

Minimalistyczna scenografia, którą tworzą jedynie pusta, ciemna scena i papierowa zasłona, osadzona w kameralnej przestrzeni kieleckiego teatru, wpisuje się w oniryczną stylistykę Schulzowskiego świata. Mocne światło latarki, którym aktor grający Józefa (Karol Smaczny) oświeca sobie z bliska twarz, wprowadza silny kontrast $z$ panującą dookoła ciemnością. Józef jest na scenie sam i tak będzie aż do końca spektaklu. Pełna ekspresji i dynamiki gra aktora, mającego za sobą doświadczenie Teatru Wierszalin, sprawia, że ani na moment nie sposób oderwać od niego wzroku. Swoją opowieść rozpoczyna słowami z opowiadania Samotność. W tle na zawieszonej płachcie papieru przemieszczają się dziwne, nieokreślone twory ze światła, niestałe, płynne, jakby ciągle nie mogły znaleźć dla siebie odpowiedniej formy.

Po chwili znikają, pozostawiając jedynie pustą, niezapełnioną przestrzeń, w której wszystko jeszcze może się pojawić. To swoista tabula rasa, którą Józef zapełnia rozmaitymi zapiskami i szkicami. Niczym szalony demiurg będzie tworzyć świat, który nie musi spełniać wymogów realności - ojciec może zmienić się w karakona, by zaraz być rakiem, a potem znów schylonym nad starymi papierami, zapracowanym kupcem bławatnym. Ten świat już kiedyś istniał, a opowieść Józefa jest jego odtworzeniem, ponownym powołaniem do życia. On stwarza na nowo ten świat, który jest piękny i tajemniczy, ale istnieje tylko przez krótką chwilę, by zaraz zniknąć i pozostawić Józefa samego, w jego pokoju z dzieciństwa, wśród starych szpargałów i wspomnień.

Kreowane przez niego twory przypominają te nieuformowane figury świetlne z początku spektaklu. Pomysł reżysera polega tutaj na tym, że na scenie znajduje się tylko aktor grający Józefa-opowiadacza, a reszta aktorów-animatorów ukrywa się za papierową zasłoną, by dać o sobie znać w postaci ukazującego się na płachcie cienia czy lalki albo za pomocą głosu. Świat tworzony przez Józefa jest papierowy, istnieje tylko na kartach jego opowiadań, podczas gdy ten realny należy już do przeszłości.

W odpryskach dawno minionych historii widzimy postaci-duchy, fantazmaty, które pojawiają się tylko wtedy, gdy Józef wywoła je z zakamarków swojej pamięci. I tak pojawia się Ojciec (Andrzej Kuba Sielski), którego potężny cień majaczy groźnie zza papierowej zasłony, pojawia się zarys sylwetki zanurzonej w głębokim śnie Adeli (Ewa Lubacz), po której bezszelestnie stąpają szeregi pluskiew, pojawia się też mały piesek Nemrod, który nawet macha ogonkiem i wykonuje treserskie sztuczki na zawołanie Józefa. 
To, co dzieje się w tle, stanowi dopełnienie opowieści Józefa, który momentami przypomina rapsoda snującego niesamowite opowieści. Jednak to nie słowo jest dominantą w tym spektaklu. Zdaje się, że wszystkie elementy dzieła teatralnego współgrają ze sobą na równym poziomie, stając się częścią ostatecznego widowiska, które jest konsekwentną realizacją koncepcji twórców.

Spektakl powstał we współpracy reżysera - Roberta Drobniucha, autora adaptacji - Tomasza Domulewicza, i twórcy lalek i scenografii - Cengiza Öze$\mathrm{ka}^{1}$. W przedstawieniu język Schulza został więc wzbogacony o formy charakterystyczne dla teatru cieni, a także o muzykę wykonywaną na żywo. Michał Górczyński, podczas spektaklu grający na klarnecie basowym, napisał muzykę razem $z$ Karolem Nepelskim. Utwory powstawały jako inspiracje do istniejących już obrazów i scen. W momencie gdy Józef krzyczy, a matka - wedle jego opowieści - zamyka mu usta ustami i krzyczy razem z nim, wtórują im piszczące, przeszywające dźwięki instrumentu. Muzyka została wkomponowana w treść spektaklu. Podobnie scenografia i lalki-cienie.

Oto na papierowej płachcie majaczy zarys domu „w rynku”, który ma tyle pokoi, że o niektórych na długie lata zapominają nawet sami domownicy. Jego dolną część wynajmują subiekci, a na strychu znajduje się ptasie królestwo Ojca. Pojawia się też makieta Drohobycza, której twórcy wzorowali się na realnej mapie miasta. Te obrazy pojawiają się i znikają, tak jak tajemnicze fantomy, które Józef przywołuje ze swojej pamięci.

Ta „niesceniczna” (jak chciało wielu krytyków teatralnych) proza znajduje więc dla siebie miejsce $\mathrm{w}$ teatrze lalek ${ }^{2}$, $\mathrm{w}$ teatrze cieni. Zbigniew Taranienko zwraca uwagę na szczególne właściwości tego typu teatru: „Dzięki swej specyfice teatr lalek pozwala na konstrukcję rzeczywistości teatralnej nieosiągalną gdzie indziej. To, co wizualne - przedmiotowa warstwa teatru, w całości poddaje się kształtowaniu. Kiedy lalkę pojmować jako dowolny kształt plastyczny, pozwalający na sceniczną animację, a nie tylko uproszczone przedstawienie człowieka czy zwierzęcia, teatr lalek przemienia się w plastyczne widowisko, stanowi pełną realizację wizji scenografa. Wtedy łatwo można wprowadzać na scenę zjawiska, które nigdy nie istniały, a jeszcze łatwiej stworzyć dla rzeczywistości teatralnej

1 Cengiz Özek, dyrektor Cengiz Özek Shadow Theatre w Stambule, znany jest jako specjalista w dziedzinie tradycyjnego teatru cieni Karagöz. Sklepy cynamonowe to spektakl wykorzystujący zupełnie inne możliwości teatralne. Özek mierzy się z mało w Turcji znaną poetycką, synestezyjną prozą Schulza, dla której poszukuje nowej formy w teatrze - porzuca pomysły inscenizacyjne wykorzystywane do ukazywania scenicznych perypetii Karagöza i jego przyjaciela Hacivata, by stworzyć wizje nieuformowane, migotliwe, płynne, jakby z pogranicza jawy i snu.

2 Proza Schulza była już wcześniej adaptowana przez teatry lalkowe, co zawsze spotykało się z pozytywnym odbiorem krytyków: Samotność, reż. F. Lazaro (1988, Teatr Lalek Banialuka w BielskuBiałej); Ostatnia ucieczka, reż. A. Maksymiak (2004, Wrocławski Teatr Lalek); Sklepy cynamonowe, reż. F. Soehnle (2008, Białostocki Teatr Lalek); Historia występnej wyobraźni, reż. K. Dworakowski (2010, Teatr Lalki i Aktora "Pinokio” w Łodzi). 
- przypominającej zwykłą, ludzką rzeczywistość - specjalne reguły; dzięki zabiegom scenograficznym można ożywić domy, zmusić do mówienia chmury, kazać latać drzewom"3.

Twórcy Sklepów cynamonowych biorą pod uwagę właśnie te możliwości kreowania wizji nieokreślonych, enigmatycznych, jednocześnie zauważając, że proza Schulza, pełna przeobrażeń, zmienności i tworów fantastycznych, z pogranicza marzenia i rzeczywistości, w pewien sposób wpasowuje się w konwencję tego teatru.

Nie jest ich ambicją stworzenie wiernej adaptacji ${ }^{4}$ opowiadań Schulza, co zdecydowanie wpływa na korzyść przedstawienia. Zmierzają raczej w stronę „adaptacji artystycznej"5, która polega na wyjściu „poza reprodukcję w stronę interpretacji”.6. Dramaturg, Tomasz Damulewicz, skupia się przede wszystkim na dwóch wątkach: fascynacji postacią Ojca i mityzacji dzieciństwa. W scenariuszu wykorzystuje fragmenty z kilkunastu opowiadań z tomów Sklepy cynamonowe (m.in. Nawiedzenie, Ptaki, Manekiny, Wichura, Nemrod) i Sanatorium Pod Klepsydra (m.in. Genialna epoka, Edzio, Samotność), a także listów Schulza (m.in. do Anny Płockier, Stanisława Ignacego Witkiewicza, Tadeusza i Zofii Brezów). Sceniczna opowieść nie zachowuje chronologii zawartej w tomach. Jest swego rodzaju kolażem rozmaitych scen, osób, sytuacji, które rozgrywały się na kartach opowiadań.

Sklepy cynamonowe nie są spektaklem usiłującym stworzyć wizję pełną i skończoną. I to zdecydowanie przesądza o sukcesie tego przedstawienia. Wielokrotne próby adaptowania prozy Schulza, zmierzające do nałożenia jakichś ograniczeń na tę poetycką prozę, nieokrzesaną niczym zapuszczony ogród, niedającą się objąć sztywnymi granicami, wymykającą się jakimkolwiek regułom, przynosiły niepowodzenia i stały się argumentem dla recenzentów chętnych określić prozę Schulza jako niemożliwą do ukazania w teatrze. Jerzy Jarzębski krytykował takie podejście twórców teatralnych: „Opowiadania Schulza - na pozór przynajmniej - nadzwyczaj rzadko [...] dążą do jakiejś wyrazistej puenty, a ich fabuła raczej nie zachowuje reguł dramatycznej konstrukcji, budowę ma natomiast, jak się rzekło, fragmentaryczną, rwaną, pozbawioną zakończeń i podsumowań $\mathrm{W}$ tej sytuacji adaptatorzy Schulza na scenę starają się konstrukcję dramatyczną skleić z owych fragmentów"7.

3 Z. Taranienko, Perspektywy lalki, w: idem, Teatr bez dramatu, Warszawa 1979, s. 33.

4 Jeżeli w ogóle można mówić o istnieniu takiej kategorii jak „wierna adaptacja”, to przecież dosłowne ukazanie historii zawartej w tekście na deskach teatru nie ma najmniejszego sensu - ani nie wzbogaci pierwowzoru, ani nie uszlachetni widowiska. Jeżeli wreszcie traktować przeniesienie treści dzieła literackiego na język teatru jako „przekład”, jak chciał tego Zbigniew Osiński, to wówczas należy założyć, że tłumaczenie zawsze niesie ze sobą - choćby drobne - fałszerstwo. Czy istnieje więc literalna adaptacja? A jeśli tak, to jaki jest jej sens?

5 J. Ciechowicz, Bruno Schulz w teatrze, "Dialog" 1993, nr 5, s. 94.

6 Ibidem.

7 J. Jarzębski, Fabryki fabulistyczne: narodziny opowieści z życia i dzieła Schulza, w: idem, Schulzowskie miejsca i znaki, Gdańsk 2016, s. 198. 
Kielecki spektakl zyskał więc na tym, że nie dążył do stworzenia całościowej, spójnej wizji z opowiadań Schulza, ale skupił się na ukazaniu jakiejś części tego świata, który wyrasta bujnie ze stron opowiadań; w całej swej niejednorodności i skłonności do przemian jawi się on przecież jako uniwersum fragmentu, zlepek form niestałych, wiecznie podlegających kolejnym transformacjom i przeobrażeniom. Koncepcja twórców Sklepów cynamonowych przypomina starą figurę retoryczną pars pro toto - pokazują widzom tylko namiastkę Schulzowskiego świata, która pozwala na stworzenie wyobrażeń na temat całości.

Sklepy cynamonowe, Teatr Lalki i Aktora "Kubuś" w Kielcach

adaptacja: Tomasz Damulewicz

inscenizacja i reżyseria: Robert Drobniuch

współpraca reżyserska: Cengiz Özek (Turcja)

scenografia i lalki: Cengiz Özek (Turcja)

muzyka: Michał Górczyński, Karol Nepelski

klarnet/ klarnet basowy na żywo: Michał Górczyński

obsada:

Józef: Karol Smaczny

Ojciec: Andrzej Kuba Sielski

Adela/Matka: Ewa Lubacz

animacja figurami, lustrami, światłem: Ewa Lubacz, Andrzej Kuba Sielski, Grzegorz Karkowski

prapremiera: 23 października 2014, Stambuł

polska premiera: 17 stycznia 2015, Kielce 